Research Article

\title{
Free-Radical Scavenging Activity (FRSA) of Secondary Metabolite Extracted from Indonesian Eucheuma Spinosum
}

\author{
Nurul Inayah ${ }^{1}$, Masruri Masruri2 ${ }^{\star}$ \\ ${ }^{1}$ Chemistry Department, Institute of Science and Technology (IST) Annuqayah, Sumenep Madura, Indonesia, 69463 \\ ${ }^{2}$ Chemistry Department, Brawijaya University, Jl. Veteran Malang, Indonesia, 65145
}

\section{ARTICLE INFO}

\section{Article History}

Received 7 December 2020

Revised 2 February 2021

Available online 8 April 2021
* Coresponding author: masruri@ub.ac.id

\section{ABSTRACT}

Indonesia is the biggest country in the production of red seaweed of Eucheuma spinosum. The red seaweed has bioactive compounds that have a potential activity such as phenolic compounds as well as carrageenan and pigments. This paper reported phytochemical analysis of $E$. spinosum harvested by a local farmer in Sumenep Island, East Java and free-radical scavenging activity (FRSA) derived from 2,2'-diphenyl-1-picrylhdrazyl (DPPH) for several organic solvents. For extraction, dried powder is added with $5.0 \mathrm{~mL}$ of various solvents following by ultrasonication assisted extraction for 30 minutes. The extract was separated by centrifugation for phytochemical analysis and radical scavenging evaluation. The prospecting of dichloromethane, ethyl acetate, and $n$-hexane extracts indicated the potency for radical scavengers. Alkaloids, terpenoids, and saponins were secondary metabolites that indicated the presence in the extracts. The best $\mathrm{IC}_{50}$ value was presented by ethyl acetate extracts $(384,86 \mathrm{ppm})$ with $38.78 \%$ for 50 $\mathrm{ppm}$, while $\mathrm{I} \mathrm{C}_{50}$ values of $\mathrm{n}$-hexane, methanolic, dicloromethane extracts were $410.12,677.76$ and $685.08 \mathrm{ppm}$, respectively.

Keywords: Eucheuma spinosum, phytochemical analysis, radical scavenging activity

\section{Introduction}

Seaweed farming has been broadly developed in Indonesia, specially Eucheuma species which has been cropped several decades ago [1]. Eucheuma spinosum or, other names, Eucheuma denticulatum (N. L. Burman) Collin [2] is the main source for carrageenan. The average carrageenan production is around 6500 tons per year [3]. Carrageenan is a natural polymer with many functions for additive, food products, and pharmaceuticals industry $[4,5]$. The carrageenan structure consists of a sulfated polysaccharide $[6,7,8]$. Carrageenan is the primary metabolite product from $E$. spinosum, and still, there is another important product that has no specific function for plants, i.e. secondary metabolite product.

Recently, many studies have been reported other functionality of secondary metabolites from $E$. spinosum which could be a potential source. The secondary metabolites are used as an anti-oxidative compound [9, 10,11, 12], anti-bacterial [13], anti-tumor [14], anti-hypercholesterolemic [15], anti-inflammation and amylase inhibition activity [16]. The secondary metabolite compounds contained in E. spinosum are alkaloids [17], flavonoids [13], isoprenoid [18], monoterpene [19], diterpene [20], and myrcene [21].

Researches of E. spinosum were reported from North Borneo (Sabah Malaysia) [9] and North Sulawesi [22, 23]. Methanolic extraction of the samples from different islands indicated the presence of phenolic and polyphenol (secondary metabolites) $[9,24]$. Predicted compounds in both samples have a simple phenolic structure, such as flavonoid and condensed tannin. E. spinosum from Bali Island (Indonesia) was extracted using ethanol and the sample contained a phenolic group with the addition of carotenoid [25]. Carotenoid is categorized as a terpenoid group and it is composed of 
poly-unsaturated hydrocarbon with 40 carbon chain. The two different structures of carotenoid are alpha- and beta-carotene [26].

The scavenging activity of free radicals is a measurement to test the ability of a compound to inhibit free radicals. The other free radical species can be generated from an electron or hydrogen radical. 2,2'-diphenyl-1-picrylhdrazyl (DPPH) has a molecular structure with the ability to transfer radical electron or hydrogen radical [27]. The radical electron can be accepted by secondary metabolite through sharing a radical proton and forms a hydrogenated-DPPH (Figure 1). This hydrogenated structure has different spectrum absorption to DPPH. Thus, it will reduce the absorption spectrum at DPPH's maximum wavelength $(517 \mathrm{~nm})$. Research on $E$. spinosum from Makassar reported had a strong antioxidant activity with an $\mathrm{IC}_{50}$ value of $75.98 \mathrm{ppm}$ [28]. Underline to those facts and some potent bioactivities from $E$. spinosum or $E$. denticulatum (N. L. Burman) Collin, exploring secondary metabolite and evaluating the bioactivities of scavenging of free radical in the seaweed become an important step for further prospecting and development.
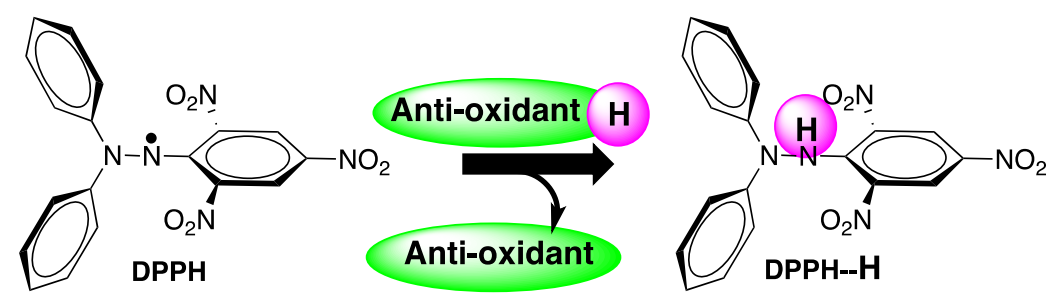

Figure 1. Schematic for anti-oxidative activity with DPPH

\section{Materials and Methods}

\subsection{Materials}

Eucheuma spinosum is purchased from a local farmer from Sumenep, East Java, Indonesia. The sample is dried under the sunlight and ground to be a dry powder. Some chemicals used are from Merck and Smartlab such as ethyl acetate, n-hexane (Smartlab), ethanol, methanol, chloroform (Smartlab), dichloromethane (Smartlab), DPPH, iron(III) chloride, acetic anhydride, and other phytochemical reagent fresh-prepared before used.

\subsection{Sample Extraction}

A $50 \mathrm{mg}$ of dried powder of $E$. spinosum in the reaction tube is added $5.0 \mathrm{~mL}$ of ethyl acetate. This mixture is sonicated for $15 \mathrm{~min}$ and centrifuged for separation of the supernatant. The supernatant is further evaporated under reduced pressure to get ethyl acetate extract and the extract is measured its phytochemical and radical scavenging evaluation. This procedure is applied using different solvents such as methanol, dichloromethane, and hexane.

\subsection{Phytochemical Evaluation}

Procedure for phytochemicals screening is undertaken following Masruri et al. [29] with modification.

\subsubsection{Alkaloid Test}

A $100 \mathrm{mg}$ of a crude extract is added $0.5 \mathrm{~mL}$ solution of hydrochloric acid $2 \%$. This is further added with Dragendorf reagent. Positive alkaloid is indicated by the orange precipitate. Another reagent is also applied using Mayer reagent. The yellowish precipitate is a positive indication of the presence of alkaloids.

\subsubsection{Flavonoid Test}

A $100 \mathrm{mg}$ of a crude extract is added $1-2 \mathrm{~mL}$ of aqueous methanol and heated. This mixture is further added with 0.5 $\mathrm{mL}$ of concentrated hydrochloric acid and magnesium powder. Positive flavonoid is detected by changing the solution color to red or orange.

\subsubsection{Triterpenoid and Steroid Test}

A $100 \mathrm{mg}$ of a crude extract in the reaction tube is added with $0.5 \mathrm{~mL}$ of acetic anhydride and $1.0 \mathrm{~mL}$ of sulfuric acid. The presence of a brown or violet's ring in the solution is a positive indication of triterpenoid. Meanwhile, the existence of steroids is indicated by the formation of a green-blue solution.

\subsubsection{Saponin Test}

The presence of saponin is tested by the formation of permanent foam. A crude extract is added $0.5 \mathrm{~mL}$ of hydrochloric acid $2 \%$. This mixture is shaken for $5 \mathrm{~min}$. Relatively permanent foam formed is a positive indication of saponin. 


\subsubsection{Tannin Test}

A $100 \mathrm{mg}$ of a crude extract in the test tube is added with $1.0 \mathrm{~mL}$ of hot methanol and $1.0 \mathrm{~mL}$ of iron(III) chloride $1.0 \%$. The presence of tannin in the extract is indicated by the formation of a dark-blue or dark-green solution.

\subsection{Evaluation Radical Scavenging Activity}

The radical scavenging activity of the E. spinosum extract is undertaken following Taroreh et al. [30] with a minor modification. A $1.0 \mathrm{~mL}$ of the extract (concentration variation 50; 100; 200; and $400 \mathrm{ppm}$ ) is added $2.0 \mathrm{~mL}$ of solution 0.08 $\mathrm{mM}$ of DPPH. This mixture is homogenized and incubated for $30 \mathrm{~min}$ at room temperature. The mixture is measured absorbance at $517 \mathrm{~nm}$. A blank sample is prepared by addition $1.0 \mathrm{~mL}$ methanol into $2.0 \mathrm{~mL}$ of DPPH solution. The percent DPPH scavenging effect was calculated using Equation 1.

$$
\text { Scavenging Activity }(\%)=\frac{A \text { blank-A sampel }}{A \text { blank }} \times 100 \%
$$

Where $A_{\text {blank }}$ is absorbance value for solution DPPH in methanol and $A_{\text {sample }}$ is absorbance value for sample.

\section{Result and Discussion}

\subsection{Extraction and Phytochemicals Screening}

Extraction with the different polarities of solvents is devoted to obtaining secondary metabolite into different solvent affinity. Most polar solvent (methanol) can dissolve secondary metabolites with high polarities, such as phenolic, flavonoid, tannin, and alkaloid compounds [12, 29]. Conversely, non polar solvent such as n-hexane can extract secondary metabolite with non polar properties, for example; triterpenoid, saponin, steroid, and less volatile alkaloid compounds [29, 31].

The phytochemical result is shown in Table 1. Methanol and ethyl acetate can be used to extract two groups of secondary metabolite i.e. triterpenoids and alkaloids for methanolic extract and also triterpenoids and saponins for ethyl acetate extract. Dichloromethane and $\mathrm{n}$-hexane extracts share a similar result, they contained triterpenoids, alkaloids, and saponins. Based on previous research, E. spinosum extract contained alkaloids [31, 32], terpenoids [33], and saponins compounds [31].

Table 1. Secondary Metabolite of Some Crude Extracts of Eucheuma spinosum

\begin{tabular}{lcccc}
\hline \multirow{2}{*}{ Secondary Metabolite } & \multicolumn{4}{c}{ Crude Extract } \\
\cline { 2 - 5 } & Methanol & Dichloromethane & Ethyl Acetate & n-Hexane \\
\hline Flavonoid & - & - & - & - \\
Triterpenoid & + & ++ & + & ++ \\
Steroid & - & - & - & - \\
Alkaloid (Dragendroff) & + & + & - & + \\
Alkaloid (Mayer) & + & - & - & - \\
Tanin & - & - & + & + \\
Saponin & - & ++ & ++ \\
\hline "++" means extract giving a deep in color or giving more precipitate, "+" means extract containing a fair \\
compound or giving light color or giving less precipitate, and "-" means no indication of a certain compound in \\
the extract.
\end{tabular}

\subsection{Free Radical Scavenging Activity}

The results of the antioxidant activity of methanolic and dichloromethane extract using DPPH scavenging are summarized in Table 2 and Table 3. Overall, methanolic and dichloromethane extracts have a similar range of free radical scavenging activity, 27.68 and $27.22 \%$ for $50 \mathrm{ppm}$, respectively. Meanwhile, the highest activity obtained was 54.62 and $56.44 \%$ for the highest concentration of extract. The $\mathrm{IC}_{50}$ value of both extracts was in a similar range $(677.76 \mathrm{ppm}$ for methanolic extract and $685.08 \mathrm{ppm}$ for dichloromethane extract. However, both extracts have different content of secondary metabolite. Saponin is detected in dichloromethane extract, but it did not detect in methanolic extract.

Based on the results, the percentage of antioxidant activity increased after increasing the concentration, it can be seen at the concentration of $800 \mathrm{ppm}$ has the highest value of antioxidant activity. The ability of DPPH radicals is influenced by the amount of extract concentration. Generally, DPPH activity is increased with the addition of the extract to a certain concentration [23]. Previous research stated that E. spinosum using methanol and ethanol solvents (concentration of $50 \%$ and $95 \%)$ has radical scavenging activity $\left(I C_{50}\right), I C_{50}$ value of $E$. spinosum using methanol 50 and $95 \%$ were 223.305 and 
$238.128 \mathrm{ppm}$, while $\mathrm{IC}_{50}$ value of $E$. spinosum using ethanol 50 and $95 \%$ were 113.882 and $97.522 \mathrm{ppm}$, respectively. The smaller the $\mathrm{IC}_{50}$ value, the higher the radical scavenging activity [34].

Table 2. Radical Scavenging Activity of Methanolic Extract

\begin{tabular}{|c|c|c|c|c|c|c|}
\hline \multirow{2}{*}{$\begin{array}{l}\text { Concentration } \\
(\mathrm{ppm})\end{array}$} & \multicolumn{4}{|c|}{ UV Absorbance measurement (a.u.) } & \multirow{2}{*}{$\begin{array}{c}\text { Radical } \\
\text { Scavenging activity (\%) }\end{array}$} & \multirow{2}{*}{$\begin{array}{l}\mathrm{IC}_{50} \\
(\mathrm{ppm})\end{array}$} \\
\hline & Blank & 1 & 2 & 3 & & \\
\hline 50 & 0.7154 & 0.523 & 0.517 & 0.512 & $27.68 \pm 0.76$ & \\
\hline 100 & & 0.507 & 0.504 & 0.495 & $29.83 \pm 0.87$ & \\
\hline 200 & & 0.483 & 0.478 & 0.458 & $33.88 \pm 1.85$ & 677.76 \\
\hline 400 & & 0.442 & 0.433 & 0.427 & $39.34 \pm 1.06$ & \\
\hline 800 & & 0.332 & 0.331 & 0.311 & $54.62 \pm 1.66$ & \\
\hline
\end{tabular}

Table 3. Radical Scavenging Activity of Dichloromethane Extract

\begin{tabular}{cccccccc}
\hline $\begin{array}{c}\text { Concentration } \\
\text { (ppm) }\end{array}$ & \multicolumn{2}{c}{ UV Absorbance measurement (a.u.) } & \multirow{2}{*}{$\begin{array}{c}\text { Radical } \\
\text { Scavenging Activity (\%) }\end{array}$} & $\begin{array}{c}\mathbf{I C}_{50} \\
\text { (ppm) }\end{array}$ \\
\cline { 2 - 5 } & Blank & $\mathbf{1}$ & $\mathbf{2}$ & $\mathbf{3}$ & & \\
50 & 0.7154 & 0.521 & 0.525 & 0.516 & $27.22 \pm 0.63$ & \\
100 & & 0.519 & 0.487 & 0.501 & & $29.78 \pm 2.24$ & \\
200 & & 0.493 & 0.489 & 0.478 & $31.97 \pm 1.09$ & 685.08 \\
400 & & 0.484 & 0.465 & 0.459 & $35.84 \pm 1.82$ & \\
800 & & 0.311 & 0.311 & 0.313 & & $56.44 \pm 0.16$ & \\
\hline
\end{tabular}

Evaluation of the scavenging activity for hexane extract showed a better result than that of methanolic and dichloromethane extract. N-Hexane extract gave radical scavenging activity of $43.43 \%$ for $50 \mathrm{ppm}$ (Table 4). The IC $\mathrm{C}_{50}$ value of the $n$-hexane extract obtained was $410.12 \mathrm{ppm}$. However, the scavenging activity of the ethyl acetate extract $\left(\mathrm{IC}_{50}=\right.$ $384.86 \mathrm{ppm}$ ) has slightly higher than $\mathrm{n}$-hexane extract (Table 5). E. spinosum extracted with methanol and partitioned with ethyl acetate have a strong free radical scavenging activity value, $I_{50}$ of $41.94 \mathrm{ppm}$ [35]. Ethyl acetate extract on $E$. spinosum contained the only terpenoid groups of secondary metabolite (triterpenoid and saponin). Terpenoids are phenolic compounds that have the potential to act as antioxidants or free radical scavengers [36, 37]. Other research stated that terpenoids are active as free radical scavengers with an $I_{50}$ value of $61 \mathrm{ppm}[38]$ and an $\mathrm{IC}_{50}$ value of $6.751 \mathrm{ppm}$ [39].

Table 4. Radical Scavenging Activity of $n$-Hexane Extract

\begin{tabular}{ccccccc}
\hline $\begin{array}{c}\text { Concentration } \\
\text { (ppm) }\end{array}$ & \multicolumn{2}{c}{ UV Absorbance measurement (a.u.) } & \multirow{2}{*}{$\begin{array}{c}\text { Radical } \\
\text { Scavenging Activity (\%) }\end{array}$} & $\begin{array}{c}\text { IC }_{50} \\
\text { (ppm) }\end{array}$ \\
\cline { 2 - 5 } & Blank & $\mathbf{1}$ & $\mathbf{2}$ & $\mathbf{3}$ & & \\
\hline 50 & 0.7154 & 0.417 & 0.371 & 0.426 & $43.43 \pm 4.12$ & \\
100 & & 0.402 & 0.347 & 0.414 & $45.81 \pm 4.99$ & \\
200 & & 0.385 & 0.385 & 0.396 & $45.67 \pm 0.89$ & 410.12 \\
400 & & 0.355 & 0.353 & 0.36 & $50.24 \pm 0.50$ & \\
800 & & 0.311 & 0.311 & 0.312 & $56.48 \pm 0.08$ & \\
\hline
\end{tabular}

Table 5. Radical Scavenging Activity of Ethyl Acetate Extract

\begin{tabular}{ccccccc}
\hline $\begin{array}{c}\text { Concentration } \\
\text { (ppm) }\end{array}$ & \multicolumn{2}{c}{ UV Absorbance measurement (a.u.) } & $\begin{array}{c}\text { Radical } \\
\text { Scavenging Activity (\%) }\end{array}$ & $\begin{array}{c}\mathbf{I C}_{50} \\
\text { (ppm) }\end{array}$ \\
\cline { 2 - 5 } & Blank & $\mathbf{1}$ & $\mathbf{2}$ & $\mathbf{3}$ & $38.78 \pm 0.14$ & \\
\hline 50 & 0.7154 & 0.437 & 0.438 & 0.439 & $39.56 \pm 0.21$ & \\
100 & & 0.431 & 0.432 & 0.434 & & \\
200 & & 0.422 & 0.418 & 0.405 & $41.99 \pm 1.24$ & 384.86 \\
400 & & 0.389 & 0.389 & 0.389 & $45.62 \pm 0.00$ & \\
800 & & 0.221 & 0.223 & 0.221 & $69.01 \pm 0.16$ & \\
\hline
\end{tabular}

\section{Conclusion}

Secondary metabolite of $E$. spinosum extract was successfully detected by the phytochemical test. Terpenoid group (triterpenoid and saponin) and alkaloid can be detected on methanolic, dichloromethane, and $n$-hexane extract. The radical scavenging activity of $E$. spinosum using four various solvents showed that ethyl acetate extract had the highest $\mathrm{IC}_{50}$ value of $384.86 \mathrm{ppm}$, and then followed by n-hexane extract (410.12 ppm), methanolic extract (677.76 ppm), and dicloromethane extract $(685.08 \mathrm{ppm})$. 


\section{Acknowledgement}

Authors thank to Dr. Edi Priyo Utomo for guidance and discussion during thesis research, and also thank to all laborants and technicians in Organic Chemistry Lab and UPT Instrumen (Mr. Hadi Kurniawan, Amd and Mr. Widji Sulistijo).

\section{References}

[1] H. Adnan \& H. Porse, "Culture of Eucheuma cottonii and Eucheuma spinosum in Indonesia," Hydrobiologia, vol. 151152, pp. 355-358, 1987.

[2] M. D. Guiry, G. M. Guiry, L. Morrison, F. Rindi, S. V. Miranda, A. C. Mathieson, B. C. Parker, A. Langangen, D. M. John, I. Barbara, C. F. Carter, P. Kuipers, \& D. J. Garbary, "AlgaeBase: An On-Line Resource for Algae," Cryptogamie. Algalogie, vol. 35, no. 2, pp. 105-115, 2014.

[3] D. J. McHugh, "Worldwide Distribution of Commercial Resources of Seaweeds Including Gelidium," Hydrobiologia, vol. 221, pp. 19-29, 1991.

[4] S. Mohamed, S. N. Hashim, \& H. A. Rahman, "Seaweeds: A Sustainable Functional Food for Complementary and Alternative Therapy," Trends in Food Science \& Technology, vol. 23, no. 2, pp. 83-96, 2012.

[5] N. Stanley, "Production, Properties and Uses of Carrageenan," in Production and Utilization of Products from Commercial Seaweeds, D. J. McHugh Ed. Rome: Food and Agriculture Organization of The United Nations, 1987.

[6] V. L. Campo, D. F. Kawano, D. B. da Silva Jr, \& I. Carvalho, "Carrageenans: Biological Properties, Chemical Modifications and Structural Analysis - A Review," Carbohydrate Polymers, vol. 77, no. 2, pp. 167-180, 2009.

[7] M. C. R. de Souza, C. T. Marques, C. M. G. Dore, F. R. F. da Silva, H. A. O. Rocha, \& E. L. Leite, "Antioxidant Activities of Sulfated Polysaccharides from Brown and Red Seaweeds, "Journal of Applied Phycology, vol. 19, no.2, pp. 153160, 2007.

[8] G. Jiao, G. Yu, J. Zhang, \& H. S. Ewart, "Chemical Structures and Bioactivities of Sulfated Polysaccharides from Marine Algae," Marine Drugs, vol. 9, no. 2, pp. 196-223, 2011.

[9] P. Matanjun, S. Mohamed, N. M. Mustapha, K. Muhammad \& C. H. Ming, "Antioxidant Activities and Phenolics Content of Eight Species of Seaweeds from North Borneo," Journal of Applied Phycology, vol. 20, pp. 367-373, 2008.

[10] M. Fayaz, K. K. Namitha, K. N. C. Murthy, M. M. Swamy, R. Sarada, S. Khanam, P. V. Subbarao, \& G. A. Ravishankar, "Chemical Composition, Iron Bioavailability, and Antioxidant Activity of Kappaphycus alvarezzi (Doty)," Journal of Agricultural and Food Chemistry, vol. 53, no. 3, pp. 792-797, 2005.

[11] S. D. Amora \& S. Sukesi, "Ekstraksi Senyawa Antioksidan pada Nugget-Rumput Laut Merah, Eucheuma cottonii," Jurnal Sains dan Seni ITS, vol. 2, no. 2, pp. C23-C25, 2013.

[12] S. Afif, A.G. Fasya, \& R. Ningsih, "Extraction, Toxicity Assay and Identification of Active Compouns of Red Algae (Eucheuma cottonii) from Sumenep Madura," ALCHEMY: Journal of Chemistry, vol. 4, no. 2, pp. 101-106, 2015.

[13] R. Thirunavukkarasu, P. Pandiyan, D. Balaraman, K. Subramaniyan, G. E. G. Jothi, S. Manikkam, \& B. Sadaiyappan, "Isolation of Bioactive Compound from Marine Seaweeds Against Fish Pathogenic Bacteria Vibrio alginolyticus (Va09) and Characterisation by FTIR," Journal of Coastal Life Medicine, vol. 1, no.1, pp. 26-33, 2013.

[14] H. Noda, H. Amano, K. Arashima, S. Hashimoto, \& K. Nisizawa, "Studies on the Antitumor Activity of Marine Algae," Nippon Suisan Gakkaishi, vol. 55, no. 7, pp. 1259-1264, 1989.

[15] T. Wresdiyati, A. B. Hartanta, \& M. Astawan, "The Effect of Seaweed Eucheuma cottonii on Superoxide Dismutase (SOD) Liver of Hypercholesterolemic Rats, "HAYATI Journal of Biosciences, vol. 15, no. 3, pp. 105-110, 2008.

[16] V. Balasubramaniam, J. C. Lee, M. F. M. Noh, S. Ahmad, I. A. Brownlee, \& A. Ismail, "Alpha-Amylase, Antioxidant, and Anti-Inflammatory Activities of Eucheuma denticulatum (N. L. Burman) F.S. Collins and Hervey," Journal of Applied Psycology, vol. 28, pp. 1965-1976, 2016.

[17] G. Guella, I. N'Diaye, M. Fofana, \& I. Mancini, "Isolation, Synthesis and Photochemical Properties of Almazolone, a New Indole Alkaloid from a Red Alga of Senegal," Tetrahedron, vol. 62, no. 6, pp. 1165-1170, 2006.

[18] M. Lohr, J. Schwender, \& J. E. W. Polle, "Isoprenoid Biosynthesis in Eukaryotic Phototrophs: A Spotlight on Algae," Plant Science, vol. 185-186, pp. 9-22, 2012.

[19] J. J. Polzin, G. L. Rorrer, \& D. P. Cheney, "Metabolic Flux Analysis of Halogenated Monoterpene Biosynthesis in Microplantles of the Macrophytic Red Alga Ochtodes secundiramea, "Biomolecular Engineering, vol. 20, no. 4-6, pp. 205-215, 2003.

[20] A.-S. Lin, E. P. Stout, J. Prudhomme, K. L. Roch, C. R. Fairchild, S. G. Franzblau, W. Aalbersberg, M. E. Hay, \& J. Kubanek, "Bioactive Bromophycolides R-U from the Fijian Red Alga Callophycus Serratus," Journal of Natural Pruducts, vol. 73, no. 2, pp. 275-278, 2010.

[21] M. L. Wise, G. L. Rorrer, J. J. Polzin, \& R. Croteau, "Biosynthesis of Marine Natural Products: Isolation and Characterization of a Myrcene Synthase from Cultured Tissues of the Marine Red Alga Ochtodes secundiramea,"Archives of Biochemistry and Biophysics, vol. 400, no. 1, pp. 125-132, 2002. 
[22] V. Dotulong, S. B. Widjanarko, Yunianta, \& L. P. Mamahit, "The Content of Total Phenols and Antioxidant Activity Three Types Sea Algae Taken at The North Sulawesi Waters," Food Science and Quality Management, vol. 17, pp. 40-46, 2013.

[23] L. J. Damongilala, S. B. Widjanarko, E. Zubaidah, \& M. R. J. Runtuwene, "Antioxidant Activity Against Methanol Extraction of Eucheuma cottonii and E. spinosum Collected from North Sulawesi Waters, Indonesia," Food Science and Quality Management, vol. 17, pp. 7-14, 2013.

[24] S. J. Lim, W. M. W. Aida, M. Y. Maskat, S. Mamot, J. Ropien, \& D. M. Mohd, "Isolation and Antioxidant Capacity of Fucoidan from Selected Malaysian Seaweeds," Food Hydrocolloids, vol. 42, pp. 280-288, 2014.

[25] K. S. M. Julyasih, I. G. P. Wirawan, W. S. Harijani, \& W. Widajati, "Aktivitas Antioksidan Beberapa Jenis Rumput Laut (Seaweeds) Komersial di Bali," dalam Seminar Nasional Akselerasi Pengembangan Teknologi Pertanian dalam Mendukung Revitalisasi Pertanian, Surabaya, 2009.

[26] A. Trchounian, M. Petrosyan, \& N. Sahakyan, "Plant Cell Redox Homeostasis and Reactive Oxygen Species," In Redox State as a Central Regulator of Plant-Cell Stress Responses, Berlin: Springer, 2016, pp 25-50.

[27] S. B. Nimse \& D. Pal, "Free Radicals, Natural Antioxidants, and Their Reaction Mechanisms," RSC Advances, vol. 5, pp. 27986-28006, 2015.

[28] M. Muawanah, A. Ahmad, \& H. Natsir, "Antioxidant Activity and Toxicity Polysaccaride Extract from Red Algae Eucheuma cottonii and Eucheuma spinosum," Marina Chimica Acta, vol. 17, no. 2, pp. 15-23, 2016.

[29] M. Masruri, M. Lutfillah, A. Sumaryanto, R. Retnowati, \& A. Aulanni'am, "The Curative Activity of Isolated Fraction from Spathodea campanulata Beauv Stem Bark on Rats Exposed to Benzopyrene," Journal of Tropical Life Science, vol. 4, no. 3, pp. 161-165, 2014.

[30] M. Taroreh, S. Raharjo, P. Hastuti, \& A. Murdiati, "Antioxidative Activities of Various Fractions of Gedi's Leaf Extracts (Abelmoschus manihot L. Medik)," Agriculture and Agricultural Science Procedia, vol. 9, pp. 271-278, 2016.

[31] B. L. Sari, N. Susanti, \& S. Susanto, "Skrining Fitokimia dan Aktivitas Antioksidan Fraksi Etanol Alga Merah Eucheuma spinosum," Pharmaceutical Sciences \& Research, vol. 2, no. 2, pp. 59-68, 2015.

[32] A. Podungge, L. J. Damongilla, \& H. W. Mewengkang, "Kandungan Antioksidan pada Rumput Laut Eucheuma spinosum yang Diekstrak dengan Metanol dan Etanol," Jurnal Media Teknologi Hasil Perikanan, vol. 6, no. 1, pp. 1. $5,2018$.

[33] V. Gressler, E. M. Stein, F. Dorr, M. T. Fujii, P. Colepicolo, \& E. Pinto, "Sesquiterpenes from the Essential Oil of Laurencia dendroidea (Ceramiales, Rhodophyta): Isolation, Biological Activities and Distribution among Seaweeds," Revista Brasileira de Farmacognosia, vol. 21, no. 2, pp. 248-254, 2011.

[34] P. Molyneux, "The Use of the Stable Free Radical Diphenylpicrylhydrazyl (DPPH) for Estimating Antioxidant Activity," Songklanakarin Journal Science of Technology, vol. 26, no. 2, pp. 211-219, 2004.

[35] U. Mardiyah, A. G. Fasya, B. Fauziyah, \& S. Amalia, "Ekstraksi, Uji Aktivitas Antioksidan dan Identifikasi Golongan Senyawa Aktif Alga Merah Eucheuma spinosum dari Perairan Banyuwangi," ALCHEMY, vol. 3, no. 1, pp. 39-46, 2014.

[36] J. B. Harborne, Metode Fitokimia: Penuntun Cara Modern Menganalisis Tumbuhan. Bandung: ITB Press, 1987.

[37] A. J. Parr, \& G. P. Bolwell, "Phenols in the Plant and in Man. The Potential for Possible Nutritional Enhancement of the Diet by Modifying the Phenols Content or Profile," Journal of the Science of Food and Agriculture, vol. 80, no. 7, pp. $985-1012,2000$.

[38] S. Wulandari \& A. Fidyasari, "Senyawa Metabolit Sekunder dan Aktivitas Antioksidan pada Ekstrak Buah Sirsak Gunung (Annona montana),"Tesis, Akademi Farmasi Putera Indonesia, Malang, 2017.

[39] B. Prayitno, K. Rosyidah, \& M. D. Astuti, "Uji Antioksidan Senyawa Terpenoid dari Fraksi M-17 Ekstrak Metilena Klorida Kulit Batang Tumbuhan Kasturi (Mangifera casturi)," Jurnal Pharmascience, vol. 3, no. 1, pp. 32-36, 2016. 